\title{
Kur'ân'ın Sosyal Medya Sorumluluğu Bağlamında Yorumlanabilecek Müdahaleleri
}

\section{Qur'ān's Interventions Being Commented in the Context of Social Media Ethics}

\author{
Bayram AYHAN \\ Doç. Dr., Niğde Ömer Halisdemir Üniversitesi, İslami Ilimler Fakültesi \\ Temel İlam Bilimleri, Tefsir \\ Assoc. Prof., University of Niğde Ömer Halisdemir, Faculty of Islamic Sciences \\ Department of Basic Islamic Sciences, Tafsir \\ Niğde, Turkey \\ byrmayhan@gmail.com \\ orcid.org/0000-0003-1851-0204
}

\begin{abstract}
Makale Bilgisi / Article Information
Makale Türü / Article Types

Geliş Tarihi / Received

Kabul Tarihi / Accepted

Yayın Tarihi / Published

Yayın Sezonu / Pub Dates

Cilt / Volume: 8 - Sayı / Issue: 2 - Sayfa / Pages: 435-45

Atıf / Cite as

Ayhan, Bayram. "Kur'ân’ın Sosyal Medya Sorumluluğu Bağlamında Yorumlanabilecek Müdahaleleri". Bülent Ecevit Üniversitesi Ilahiyat Fakültesi Dergisi 8/2 (2021), 435-456.

Doi: 10.33460/beuifd.1008863

Intihal / Plagiarism

Bu makale, en az iki hakem tarafından incelendi ve intihal içermediği teyit edildi.

This article has been reviewed by at least two referees and scanned via a plagiarism software.

Yayın Hakkı / Copyright ${ }^{\circ}$

CC BY-NC-ND 4.0 | Zonguldak Bülent Ecevit Üniversitesi, İlahiyat Fakültesi tarafından yayınlanmıştır. Telif ve yayın hakları, Creative Commons Atıf-Gayri Ticari-Türetilemez 4.0 lisansının hüküm ve koşullarına tabidir.

CC BY-NC-ND 4.0 | Published by Zonguldak Bulent Ecevit University. Copyrights are subjected to the terms and conditions of a Creative Commons Attribution-NonCommercial-No Derivatives License 4.0.
\end{abstract}

Öz: Teknoloji çağını yaşayan modern insanlar internetten ve sosyal medyadan büyük oranda müstağni kalamamaktadır. Gerek dünya ölçeğinde gerekse toplumumuzda sosyal medya kullanım oranlarına dair veriler vakıayı açıkça ortaya koymaktadır. Makalenin konusu aktüel bir sorun olan sosyal medya sorumluluğunu ve dezenformasyonu Kur'ân'ın nüzul sürecindeki bazı olaylara müdahalesi bağlamında ele almaktır. Günümüzde siyasi veya dini saiklerle sosyal medyada hem kişileri hem de toplumun büyük kitlelerini ilgilendiren konulara dair gerçeği yansıtmayan paylaşımlar kişilerin veya kurumların itibarına kastetmeyi amaçlamaktadır. Yanı sıra mahremiyet ihlalleri yapılmakta ve toplumun ahlaki değer yargıları ve yönelimleri değişime uğramaktadır. Daha da tehlikeli olanı ise toplumda çatışma ortamı meydana getirebilecek provokatif paylaşımlara bilgisiz ve sorumsuzca aracı olunmasıdır. Mezkûr durumların yaşanmaması için bireylerin yapması gereken şey, sosyal medya içeriklerini incelemesi, yetkili kişi ve kurumların onayı ile doğruluğunu teyit ettikten sonra paylaşmasıdır. Bu bağlamda çalışmada Kur'ân'ın 
gerek bireysel, gerekse toplumsal mağduriyetler oluşturabilecek haberlerin paylaşımı konusundaki yaklaşımı ve bazı dönemlerdeki olaylara müdahalesi ele alınacaktır. Kur'ân nüzul sürecinde kendisine inansın ve inanmasın çok büyük kitlelere aynı anda ulaşabilen ilahi bir metindi. Dolayısıyla Kur'ân bir nevi sosyal medya işlevi gerçekleştirmiş ve bu rolünü de bazı dönemlerde aktif bir şekilde işlevselleştirmiştir. Bunun yanı sıra Kur'ân toplumsal hassasiyetlerin zirvede olduğu dönemde bir bilginin/haberin paylaşımı bağlamında sosyal medya sorumluluğuna dair ana umdeler şeklinde değerlendirilebilecek önemli tespitler ortaya koymuştur. Daha da önemlisi, bazı dönemlerde kirli planlarla toplumu manipüle etmek isteyenlere fırsat vermemiş, olayları en şeffaf yönüyle tavzih etmiştir. Bu bağlamda makalede Kur'ân'ın bu yöndeki müdahaleleri aktüel bir okumaya tabi tutulacak, birey ve toplumların sorumluluklarına dair evrensel mesajları ortaya çıkarılacaktır.

Anahtar Kelimeler: Tefsir, Kur'ân, Sosyal Medya, Bireysel ve Toplumsal Sorumluluk, Yalan Haber.

\begin{abstract}
Modern society living in the age of technology, substantially, cannot stay away from the internet and social media. The data on social media usage rates both in the world and in our society reveal the case clearly. The article subject is on social media ethics and disinformation that are big trouble in the context of the Qur'änic response to certain incidents that occurred in the revelation period. Nowadays, it aims to be discredited of persons and institutions via postings that do not reflect the reality on political or religious reasons at the social media on issues that concern both individuals and the vast majority of people Besides, that privacy violations are being made and moral values and orientation of society can be changed. Even more dangerous is being made conduce to provocative posts that may create an atmosphere of conflict in society ignorantly and irresponsibly. Privacies violated, on the one hand, moral values and orientation of society corrupted on the other. Even more dangerous is to mediate irresponsibly provocative posts that may cause a chaotic atmosphere in the population. To avoid the aforementioned situations, individuals should review social media content and share it after confirming its accuracy by authorized persons and institutions. In this context, we will examine the Qur'an's approach to the spread of news that may create both individual and social grievances and its intervention in the events of some periods. The Qur'an was a Divine Text that was able to reach simultaneously large majorities in the revelation process, whether they believed in it or not. The Qur'än, in a sense, performed social media functions and has also actively performed this role in some periods. Besides, that the Qur'än presents important findings on social media responsibility in the context of news/information sharing at the height of social sensitivities periods. More importantly, in some periods, the Qur'än has not allowed who wanted to manipulate the society with hostilities and has transparently described the events In this context, in the article, the Qur'än's interventions be deeply analysed by further reading, and its universal messages individual and social responsibilities related will be revealed.
\end{abstract}

Keywords: Exegesis, Qur'ān, Social Media, Individual and Social Responsibility, Fake News. 


\section{Giriş}

Sosyal medya teknolojinin büyük bir hızla ilerlediği, akılı telefonların hayatımıza girmesiyle birlikte kitlelere ulaşım hızı ve toplumsal etkinliği dikkat çekici şekilde yükselen post-modern bir olgudur. Öyle ki sosyal medya ile ülkelerde devrim yapılabilmekte, büyük kitle hareketleri tetiklenebilmektedir. ${ }^{1}$ Bazı internet sağlayıcısı tarayıcılar sosyal medya entegrasyonuna imkân tanıyarak halk kitlelerini illegal/gayr-ı resmî yollardan desteklediklerini belirtmişlerdir. ${ }^{2}$ Konu üzerine araştırma yapan uzmanlar birkaç yıl öncesine oranla iletişimin artık basit bir durum olduğuna temas etmişlerdir. Kitleler, herhangi bir konuda seslerini duyurmak için ulusal veya uluslararası haber kanallarına ulaşma ihtiyacı duymadan kendi sosyal iletişim ağları üzerinden çok kısa sürede organize olabilmektedirler. Ülkemizde de özellikle Gezi kalkışması olarak isimlendirilen ve milyarlarca dolarlık zarara yol açan olaylarda da sosyal medyanın çok etkin rol aldığı tespit edilmiştir. ${ }^{3}$ Sosyal medyanın artık globalleşen dünyada çok etkin bir iletişim aracı olduğu tartışmasızdır. Özellikle herhangi bir ülkede kaos çıkartmaya hizmet eden eylem, söylem ve içeriklerin tüm dünyaya bir anda servis edilebildiği en etkin araç olduğu da vakıadır. ${ }^{4}$ Aynı şekilde Myanmar'daki Müslüman katliamı dâhil bazı iş savaşlarda sosyal medyanın aktif bir rol aldığı resmi olarak kanıtlanmıştır. ${ }^{5}$

Sosyal medyanın önemli bir kitlesel iletişim aracı olduğuna ve bunun devletler arası olaylarda da etkin olarak kullanıldığına dair bilgiler verildi. Bir diğer konu ise sosyal medyada paylaşılan verilerin güvenilirliğidir ki konumuzu ilgilendiren esas olgu budur. Zira, yine sosyal medyadaki haberlerin güvenilirliği bağlamında yapılan çalışmalar yalan haberlerin doğru haberlerden daha fazla dikkat çektiği ${ }^{6}$

117 Aralık 2010 tarihinde Tunus'ta 26 yaşındaki Muhammed Buazizi devlet içerisindeki usulsüz yapılaşmaya dikkat çekmek için kendini ateşe verir ve 4 Ocak 2011 'de hayatını kaybeder. Sosyal medyada çok kısa sürede paylaşıma giren bu olaydan sonra Tunus devlet başkanı kitlelerin protestoları sonrası istifa eder ve bu olay Arap Baharı olarak tesmiye edilerek sırasıyla Mısır devrimini ve diğer birçok Arap ülkesinde devrimin ilk tetikleyicisi olur. Ayrıntılı bilgi için bk. Mehmet Emin Babacan, İrfan Haşlak, İsmail Hira, "Sosyal Medya ve Arap Baharı", Akademik İncelemeler Dergisi, 6/2 (2011), 63-91. Ayrıca bk. https://www.yenisafak.com/dunya/kendisi-ile-arap-dunyasinibir-anda-atese-veren-isim-muhammed-buazizi-3590128 (Erişim, 19.09.21)

2 Tunus devlet başkanı Zeynel Abidin b. Ali'nin istifasının Ardından Mısır'da ülkeyi 30 yıldır yöneten Hüsnü Mübarek'i koltuğundan eden ayaklanma yaşanır. 1977'den sonraki en büyük halk ayaklanması olarak kaydedilen bu ayaklanma Twitter ve Facebook üzerinden organize edilir. Hükümet iletişimi engellemek için önce sosyal medyaya erişimi daha sonra tümüyle internet erişimini engeller. Google, bu süreçte protestocuların internet erişimine takılmadan haberleşebilmeleri için cep telefonlarına entegre bir sistem kurarak iş birliği yaptığını daha sonra açıklar. Ayrıntılı bilgi için bk. Azime Telli, "Mısır Devrimi'nde Sosyal Medyanın Rolü", Bilge Strateji Dergisi, 4/7, (Güz 2012), 66-91.

3 Nagihan Tufan Yeniçıktı, “iletişimsel Eylem Ve Facebook: Gezi Parkı Olaylarında Sosyal Medyanın Gücü”, Selçuk Iletişim Dergisi, 8/2 (Bahar 2014), 263-284.

4 Gezi Parkına ait bir hashtag 31 Mayıs 2013 tarihinde dünya ölçeğinde twitter'da 'trend topics/TT' olmuştur ve bu tarihten sonra sosyal medyanın etkinliği fark edilerek kontrol edilmesi gerektiği ilk defa gündeme gelmiştir. http://www.bilisimdergisi.org.tr/s156/pdf/50-63.pdf (Erişim, 19.09.2021)

5 The Guardian'ın haberine göre Facebook Myanmar'daki etnik soykırımı destekleyecek şiddet içerikli sayfaları bilerek ve planlayarak ön plana çıkararak ilgili olaylarda dolaylı rol oynamıştır. Benzer durumun Etiyopya'daki iç karışıklıklar için de tespit edildiği ifade edilmiştir. https://www.haber7.com/teknoloji/haber/3148908myanmardaki-katliamin-altindan-facebook-cikti (Erişim, 9.10.2021)

6 Ayrıntılı bilgi için bk. İbrahim Yıldız, "Hucurât Sûresinin 6. Âyeti Bağlamında Sosyal Medyadaki Gerçekdışı Haberler", Eskişehir Osmangazi Üniversitesi Ilahiyat Fakültesi Dergisi, 8/2 (Eylül 2021), 162-164. 
ve paylaşılma eğiliminin daha yüksek olduğunu ortaya koymuştur.7 Kitlelerin manipüle edilebilmesi için bazen şartlar uygundur veya hassas konular vardır ve toplum mühendisliği konusunda uzman olan bireyler, bu konular üzerinden başarılı eylemlere girişebilir ve amaçlarına da ulaşabilirler. Bu bağlamda ülkemizde son dönemlerde yabancı düşmanlığı/etnik kimlik tanımlamaları üzerinden söylem geliştirilmesi buna örnek olarak zikredilebilir. Haddizatında yabancı düşmanlığı Avrupa'nın uzun süre mücadele ettiği ve en nihayetinde çözümlemek adına devlet eliyle müdahale ettiği bir alandır. Zira yabancı düşmanlığı öyle bir hal almıştır ki, aşırı sağcı siyasi söylem İslam ve yabancı düşmanlığı üzerinden ciddi oy toplayabilmiştir ve bu Avrupa'yı korkutmaya yetmiş ve bazı tedbirler alınmak zorunda kalınmıştır. ${ }^{8}$ Bu bağlamda ülkemizde de adi bir vaka kişiler üzerinden değil, "etnik kimlik" üzerinden okunmaya çalışılmış ve devlet erkleri olaya müdahil olmuş, olayın provoke edilmesine müsaade etmemiştir. ${ }^{9}$ Toplumda infial oluşturabilecek mahiyetteki birçok vahşice işlenmiş cinayetlerin de etnik kimlik bağlamında okunmaya çalışılması sadece toplumdaki gerginliklerin artmasını ve huzurun bozulmasını isteyen yapılara hizmet ettiğini unutmamak gerekir. ${ }^{10}$

Aktüel birer konu olarak, çok yakın bir tarihte özellikle politik malzeme olarak kullanılan üç haberin yalan olduğu ortaya çıkmış olmasına rağmen yalan haber üzerinden bazı söylemlerin devam ettiği görülmüştür. Bu haberlerin birisi, ülkemizde hassas konulardan olan mülteciler üzerinden uydurulmuş olup, dış basına yansımış ve yalan olduğu bizzat ilgili kişiler ve kurumlar tarafından defâatle beyan edilmiş olmasına rağmen haber bazı yayın organları ve sosyal medya platformlarında gerçekmiş gibi aktarımı devam etmiştir. ${ }^{11}$ Yine aktüel bir haber olan ülkemizin bir bölgesinde meydana gelen ve onlarca insanımızın hayatını kaybetmesine sebep olan aşırı yağıştan sonra bazı sosyal medya platformlarında bir yalan haber

7 Amerika Birleşik Devletleri'ndeki Massachusetts Teknoloji Enstitüsü tarafından yapılan ve Science dergisinde yayınlanan bir araştırmaya göre sosyal medya kullanıcılarının yalan haberleri paylaşma eğilimi $\% 70$ daha fazladır ve yalan haber doğru olandan altı kat daha hızı yayılıyor. https://www.dw.com/tr/sosyal-medyada-yalan-haberdaha-\%C3\%A7ok-tutuluyor/a-42902833 (Erişim, 19.09.2021)

8 Fatma Yılmaz, Avrupa'da Irkçılık ve Yabancı Düşmanlığı, (Ankara: Uluslararası Stratejik Araştırmalar Kurumu, 2008), 112-118; Nurgül Bekar, “Avrupa Birliği Ülkelerinde Yabancı Düşmanlığı ve Avrupa Güvenliğine Etkisi”, Bilge Strateji, 10/18 (Bahar 2018), 111-142.

9 https://www.yenisafak.com/gundem/altindagda-buyuk-provokasyon-yabanci-uyruklulara-saldirip-polisaracini-tasladilar-3677090 (Erişim, 10.09.2021)

10 Konya'da bir aileden 7 kişinin vahşice katledilmesi olayını etnik kimlik üzerinden politize ve provoke etmek suretiyle buradan rant devşirmeye çalışan siyasi yapılar zikredilebilir. Toplumun her kesiminden ve tüm siyasi partilerden temsilciler olayı telin etmiştir. https://www.bbc.com/turkce/haberler-turkiye-58029461 (Erişim tarihi, 10.09.2021) Yine toplumdaki herkesin telin ettiği bir başka olay 2017 yılında Sakarya'da vuku bulmuş, Suriye uyruklu hamile bir kadına tecavüz edilmiş, mazlum kadın bir yaşındaki oğlu ile birlikte başları taşla ezilerek hunharca katledilmiştir. Tüm sivil toplum kuruluşları bu olayı telin etmiş, olayın ilgili kişilerin etnik kimliği ekseninde değerlendirilemeyeceğine özellikle vurgu yapılmıştır. https://www.milliyet.com.tr/gundem/vahset-hamile-kadina-tecavuz-edip-cocugu-ile-birlikte-oldurduler-2480487 (Erişim, 11.09.2021)

11 Özellikle ülkemizde hassas konulardan birisi olan mülteciler bağlamında muhalif bir söylem olarak gündeme getirilen 'Afgan mültecilerin Türkiye'ye yerleştirileceği' haberi bizzat kaynağından yalanlanmış olmasına rağmen haber sitelerinde tekrar dile getirilmeye devam etmiştir. https://www.bbc.com/turkce/haberler-turkiye-58298971 (Erişim, 19.09.2021) 
üretilmiş ve milyonlarca kişi bu haberi ya paylaşmış veya beğenerek yalana ortak olmuştur. ${ }^{12}$ Toplumumuzun hassas olduğu bir diğer konu olan kadın cinayeti ve cinsel istismar üzerinden kurgulanan bir haberde, tecavüze uğradığını söyleyen bir bayan tecavüzcülerin serbest kaldığını söyleyerek, pusuda bekleyenlere adeta paha biçilmez bir fırsat sunmuştur. ${ }^{13}$ illgili haber kısa süre içerisinde binlerce kişi tarafından paylaşılmış ve Cumhurbaşkanlığı İletişim Başkanlığı bu haberin yalan olduğunu, ilgili haberi paylaşan kişinin de erkek olduğunu açıklayarak kamuoyunu aydınlatmıştır. ${ }^{14}$

Sosyal medyadaki yalan haberler sadece ülkemizin değil, dünyadaki birçok ülkenin de sorunları arasında yer almaktadır. Örneğin Almanya, yükselen aşırı sağ ve göçmen karşıtı yapılanmaların sosyal medyadaki yalan haberler ile toplumu manipüle etmelerini önlemek amacıyla sosyal medya düzenlemesi yapmıştır. ${ }^{15}$ Benzer bir karar da ülkemizde yasalaşmış ve sosyal medya sağlayıcılarının toplumu provoke edecek bilgi, haber veya paylaşımlar sonrası durumun gerekliliğine göre bazı yaptırımların uygulanması kabul edilmiştir. ${ }^{16}$ Sosyal medyadaki yalan haberler, ${ }^{17}$ bunların hukuki sorumlulukları ${ }^{18}$ ve bazı dini grupların sosyal medya paylaşımlarının aktüel ve dinî değeri üzerine ${ }^{19}$ epeyce çalışma yapılmıştır.

Yukarıda zikredilenler arasından birkaç olgu dikkat çekicidir. Yalan bilgi ve haberlerin paylaşılma eğiliminin ve etkinliğinin daha fazla olması önemli bir

1211 Ağustos 2021 tarihinde Kastamonu'nun Bozkurt ilçesinde meydana gelen ve aşırı yağıştan kaynaklı sel felaketinin bölgedeki HES'ten kaynaklandığına dair yalan haberler üretilmiştir. Hem DSI genel müdürlüğü hem de bizzat Içişleri Bakanlığı bölgede havzalı, yani su tutacak şekilde yapılmış herhangi bir baraj temelli santral olmadığını söylemesine ve bölgeden görüntülerle bu dile getirilmiş olmaşna rağmen Twitter'da yalan haber üzerinden binlerce paylaşımın yapıldığı hashtag açılmıştır. Haberler için bk. https://tr.euronews.com/2021/08/14/ dsi-genel-muduru-bozkurt-ta-hes-patlad-iddialar-n-yalanlad (Erişim, 19.09.2021) https://www.bbc.com/turkce/ haberler-dunya-58187729 (Erişim, 15.09.2021) https://twitter.com/hashtag/HestirinGidin?src=hashtag click (Erişim, 16.09.2021)

13 https://twitter.com/search?q=ecemg\%C3\%BC\%C3\%A7l\%C3\%BCk\&src=typed query (Erişim, 02.09.2021); https://eksisozluk.com/ecem-gucluk--6989067 (Erişim, 12.09.2021)

$14 \mathrm{https://tr.sputniknews.com/20210729/altundan-dezenformasyonda-ecem-gucluk-ornegi-paylasimlar-}$ baskasina-ait-1045085502.html (Erişim, 10.09.2021)

15 https://www.bbc.com/turkce/haberler-dunya-53414098 (Erişim, 15.09.2021)

16 https://www.trthaber.com/haber/gundem/sosyal-medya-duzenlemesi-yasalasti-505405.html (Erişim, 19.09.2021)

17 Örn. bk. Yakup Toktay, Ali Murat Kırık, "Sosyal Medyada Dezenformasyon, Manipülasyon ve Propaganda Etkisi: Zeytin Dalı Harekatı Örneği", Sosyal Bilimler Alanında Akademik Çalışmalar, ed. Hasan Babacan, (Ankara: Gece Kitaplığı, 2020), 493-522; Hicran Özlem Ilgın, "Sosyal Medyada Dezenformasyon ve Halkla İlişkiler iliş̧kisi" İletişim Çalışmaları Dergisi, $7 / 2$ (2021), 303-322; Yıldız, "Hucurât Sûresinin 6. Âyeti Bağlamında Sosyal Medyadaki Gerçekdışı Haberler", 166-168.

18 Örn. bk. M. Raşit Akpınar, 'İslam Hukuku Açısından Sosyal Medya', Süleyman Demirel Üniversitesi Sosyal Bilimler Enstitüsü Dergisi, 28/3 (2017), 493-509; Nilüfer Sena Çalık, Beden,'Mesken ve Bilgi Mahremiyeti Açısından Sosyal Medyadaki Tasarrufların Fıkhî Açıdan Değerlendirilmesi', Türk Akademik Araştırmalar Dergisi, 3/1, (Haziran, 2018), 25-44; Sevdegül ÇEKiç, Tevhit Ayengin, "Sosyal Medyadaki Mahremiyet İhlallerinin Bazı Fıkhî Yansımalarına Dair", Mütefekkir, 8/15 (Haziran 2021), 71-93.

19 Ahmet Sait Sıcak, "Sosyal Medyada Kur'ân Kaynaklı Paylaşımlar -Saffât Suresi 25. Ayet Özelinde-", Modernleşme Sürecinde Müslümanlar, (Ankara: Nobel, 2018), 157-203; Yavuz Sefer, "ilahiyat Fakültesi Öğrencileri Örnekleminde Problemli Sosyal Medya Kullanım Ölçeği Geliştirme: Geçerlik-Güvenirlik Çalışması", Harran Üniversitesi İlahiyat Fakültesi Dergisi, 26/44, (Bahar, 2020), 109-124; Eyyüp Kayacı, “Imam Hatip Lisesi Öğrencilerinin Sosyal Medyaya İlişkin Tutumlarının İncelenmesi", Trabzon Ilahiyat Dergisi,8/1, (Güz, 2021), 39-74; Recep Emin Gül, "Sosyal Medyada Hadis Kullanımı -Facebook ve Twitter Özelinde-", Yüzüncü Yıl Üniversitesi Sosyal Bilimler Enstitüsü Dergisi, 30/2, (Bahar 2016), 163-182. 
tespittir. Binaenaleyh, yalan olduğu bilindiği halde bazı haberlerin sorumsuzca paylaşılmaya devam etmesi dikkat çekici bir veridir. İletişim Bakanlığı bu durumu 'sistematik dezenformasyon ve yalan terörü' şeklinde tanımlamayı uygun görmüş ve bununla mücadele etmek için enformasyon birimi kurmuştur. ${ }^{20}$

Biz, çalışmamızda aktüel bir yönü de olan sistematik dezenformasyon olgusunu Kur'ân'ın müdahalesi ekseninde analitik bir okumaya tabi tutacak ve bir makalenin sınırlarını aşmayacak şekilde açıklamaya çalışacağız. Öncelikle Kur'ân'ın nüzul sürecinde geniş kitlelere ulaşabilmek yönüyle sosyal medya işlevi gördüğünü söylemek mümkündür. Bu bağlamda ilk etapta Kur'ân'ın sosyal medya işlevi gerçekleştirirken evrensel bir mesaj vererek sosyal medya ahlakı veya topluma karşı sorumluluğa dikkat çektiğini görebilmekteyiz. Çalışmanın bundan sonraki ilk başlığı bir haberin sorumsuzca paylaşımı bağlamında sosyal medya ahlakı üzerine şekillenecektir. Kur'ân'ın nüzul sürecinin Medine döneminde dezenformasyona ve toplumu provoke edecek söylem ve eylemlere müdahil olmak suretiyle bir nevi sosyal medya işlevi gerçekleştirdiğini görebilmekteyiz. Bu yönüyle tam olarak "toplumu doğru bir şekilde bilinçlendirme" yani enformasyon yaptığı ifade edilebilir. Bir diğer rolü ise, toplumu tahrik eden kişilere dünyevi ve uhrevi bazı müeyyidelerin var olduğunu söyleyerek onlara karşı bir nevi sosyo-psikolojik önlemler almış olmasıdır. Makalede zikredilen olgular, ilgili ayetler bağlamında makalenin sınırlarını aşmayacak ve makalenin kapsamı dışındaki konuları dışarıda bırakacak şekilde ele alınacaktır. Müfessirler genellikle benzer yorumlar yaptıkları için rivayetlere ve kaynaklara dair sınırlandırma yapılacaktır. Farklı görüşler zikreden müfessirler var ise onlara yer verilecek; eğer yorumlar benzer ise isimlere yer verilmeyecektir.

\section{Kur'ân'ın Sosyal Medya Sorumluluğu Bağlamında Değerlendirilebilecek Söylemleri}

Kur'ân geniş kitlelere ulaşabilme imkânı sayesinde bazı toplumsal olaylara ve olgulara müdahil olmuş bazen tavzihte bulunmuş bazen de çözümler sunmuştur. Biz de ilk olarak özellikle toplumu ilgilendiren bazı konularda bireysel ve toplumsal sorumluluklar bağlamında Kur'ân'ın bakışını ele alacağız.

\subsection{Topluma Karşı Bireysel Sorumluluk}

Kur'ân, toplumsal hassasiyetlerin üst seviyelerde olduğu zaman dilimlerinde bireylerin bilgi paylaşımına dikkat etmesi gerektiğinin altını çizer. Bu bağlamda kişinin her duyduğu şeyi hiç araştırmadan başkasına aktarmasının çok büyük sorumsuzluk olduğunu izhar ederken, çözümü de sunar. Çözüm, kişinin duyduğu

20 https://tr.sputniknews.com/20210729/altundan-dezenformasyonda-ecem-gucluk-ornegi-paylasimlarbaskasina-ait-1045085502.html (Erişim, 19.09.2021) 
bir haberi konunun uzmanlarına teyit ettirmesidir. ${ }^{21}$ ilgili ayet lafız ve meali itiba-

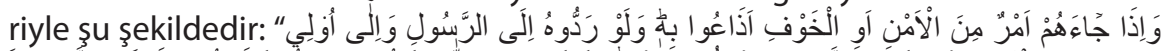
"Kendilerine güven veya korku veren bir haber geldiğinde onu yayıyorlar. Hâlbuki onu Resûlullah'a ve aralarından yetki sahibi kimselere götürselerdi, içlerinden haberin mana ve maksadını çıkarabilenler şüphesiz onu anlarlardı. Size Allah'ın lütfu ve rahmeti olmasaydı, azınız müstesna, şeytana uyup giderdiniz."22 Müfessirlerin bu ayet ile ilgili yorumları farklılaşmaktadır. Kimilerine göre buradaki durum herhangi bir zaman diliminde meydana gelen savaş hali ile ilgilidir. ${ }^{23}$ Bu bağlamda ayetin muhatabı müminler veya münafıklar olabilir. Müminler bir savaşta lehte veya aleyhte meydana gelen durumu Hz. Peygamber veya ileri gelen Müslümanlar ile görüşmeden ifşa ediyorlardı. Muhatabın münafıklar olduğunu düşünenlere göre, münafıklar Hz. Peygamber savaş veya zafere dair herhangi bir bilgi paylaşacak olursa onu düşman tarafına ulaştırırlardı. Aynı şekilde düşmanların savaşa dair hazırlıklar yaptığını öğrenince de bunu toplumun içerisinde yayıyorlar, zayıf müminlerin savaşa katılmalarını böylelikle engellemiş oluyorlardı.. ${ }^{24}$ Veyahut müminler bir seriyyede galip olduğunda bu olayı tahkir eder, bir mağlubiyet olduğunda ise olayı büyütür ve müminleri psikolojik olarak zayıflatmaya çalışırlardı. ${ }^{25}$

Kanaatimizce, muhatapların Müslümanlar olması gerektiğine dair yorum²6 daha isabetlidir. Zira münafıkların işittikleri herhangi bir bilgiyi Hz. Peygamber'e veya müminlerin ileri gelenlerine aktarmaları beklenecek bir davranış değildir. Dolayısıyla işittikleri herhangi bir haberi konuya dair bilgi sahibi olanlara arz etmeden bilinçsiz ve sorumsuzca aktaran müminlerin uyarılmış olması daha

21 Bu bağlamda Hucurât sûresinin 6. Ayeti de önem arz etmektedir. Bir makalenin sınırlarının aşılmaması adına ilgili ayete dair şu önemli çalışmaya bakılabilir. Yıldız, "Hucurât Sûresinin 6. Âyeti Bağlamında Sosyal Medyadaki Gerçekdışı Haberler", 166-168.

22 en-Nisâ, 4/83.

23 Ebû Muhammed Hasan b. Mesûd el-Begavî, Tefsîru'l-Begavî: Meâlimu't-Tenzîl, thk. Muhammed Abdullah enNemr (Riyad: Dâru Tayyibe li'n-Neşr, 1989), 2/254-255; Ebu'l-Hasan Muhammed el-Vâhidî, el-Vasît fî tefsîri'lKur'ani'l-mecîd, thk. Adil Ahmed Abdulmarsud (Beyrut: Dâru'l-Kutubi'l-'Ilmiyye, 1994), 2/87; Muhammed b. Yusuf Ebû Hayyân, Tefsîru'l-baḥri'l-muhît, thk. Adil Ahmed Abdulmevcud (Beyrut: Dâru'l-Kutubi'l-'ilmiyye, 1993), 3/318 (Ebû Hayyân, Müslim rivayetine binaen Hz. Peygamber'in eşlerini boşadığına dair söylemlerin ifşa edilmesi üzerine ayetin indiğini zikretmiştir.)

24 Ebû Câfer Muhammed b. Cerîr et-Taberî, Câmiu'I-beyân an te'vîili âyi'l-Kur'ân, thk. Abdullah bin Abdulmuhsin etTürkî (Kāhire: Merkezu'I-Buhûs ve'd-Dirâsâti'I-'Arabiye, 2001), 7/254-255; Ebû Mansur Muhammed el-Mâturîdî, Tevilâtu ehli's-sünne: Tefsîru'l-Mâturîdî, thk. Mecdî Basillûm (Beyrut: Dâru'l-kutubi'l-'ilmiyye, 2005), 3/275-276; Vâhidî, el-Vasît, 2/87; Muhammed Tâhir İbn Âşûr, Tefsîru't-Tahrîr ve't-tenvîr, (Tunus: ed-Dâru't-Tunusiyye, 1984), $5 / 139$.

25 Muhammed b. Ömer ez-Zemahşerî, el-Keşşâf an hakâiki gavâmidi't-tenzîli ve 'uyûni'l-eḳvâli fi vucûhi't-te'vîl, thk. Adil Ahmed Abdulmevcud (Riyad: Mektebetu'l-Abikan, 1998), 2/116; Begiavî, Meâlimu't-Tenzîl, 2/255; Ebû Muhammed Abdullah b. Gālip Ibn Atiyye, el-Muharreru'I-vecîz fi tefsîri'l-Kitâbi'l-'Azîz, thk. Abdusselam Abduşşâfî (Beyrut: Daru'l-kutubi'l-'ilmiyye, 2001), 2/84; ; Ebû Abdillâh Fahrüddîn Muhammed b. Ömer b. Hüseyn er-Râzî, Mefâtîhu'I-Gayb: tefsîru'r-Râzî (Lübnan: Dâru'I-Fikr li't-Tabaa ve'n-Neşr, 1981), 10/204.

26 Nâsırüddîn Ebû Saîd Abdullāh b. Ömer b. Muhammed el-Beydâvî, Tefsîru'I-Beydâvî: Envâru'-Tenzîl ve Esrâru't-te'vîl, thk. Muhammed Abdurrahman el-Maraşlî (Beyrut: Dâru İhyâi'tTurâsi'l-'Arabî, 2001), 2/87. 
isabetli bir yorum olacaktır. ${ }^{27}$ Mezkûr âyette işitilen bir bilginin Hz. Peygamber'in yanı sıra istinbat (hüküm çıkarma/yorumlama) yapabilenlere aktarılmasına matuf ifade manidardır. Söz konusu kişilerin kimler olduğuna dair hulefâ-yı râşidîn, idareciler, alimler veya fakihler zikredilmişse ${ }^{28}$ de bu kapsamın geniş̧letilebilmesi mümkündür. Yine teyit edilmeden ifşa edilen/paylaşılan bilginin sadece savaş şartları ile sınırlandırılması gerekmez. Âyet, tüm zaman ve zeminlerde uygulanabilir bir mesaj/maksadı içermektedir. Bu bağlamda âyet muhtevası itibariyle evrensel bir okuma yapabilme imkânı tanımaktadır. Dolayısıyla bilginin kendilerince teyit edilmesi gereken kişilerin de aktüel bir mahiyette konunun uzmanları veya yetkililer olarak anlaşılması da mümkündür. Bir haberin doğruluğunun teyit edilmeden kitlelere ulaştırılması tehlikeli sonuçlara sebebiyet verebilir ve nitekim ilgili ayet modern dönemde kitleleri bilgilendiren medyanın duyarlılığı ekseninde yorumlanmıştır. ${ }^{29}$ Biz âyetin mesajının daha güncel bir şekilde herhangi bir haberi/bilgiyi teyit etmeden paylaşan tüm sosyal medya kullanıcılarına matuf yorumlanabileceğini düşünmekteyiz.

Sonuç olarak Nisâ sûresi 83. âyeti işittiği herhangi bir bilgiyi soruşturmadan aktaran münafıkları veya imanı zayıf olan müminleri eleştirirken hem evrensel hem de aktüel bir mesaj vermektedir. Âyetin evrensel bir okumayla herhangi bir dönemde yaşayan ve içerisinde yaşadığı topluma karşı sorumlulukları olan insan tipolojisini betimlediğini söylemek mümkündür. Aynı şekilde nüzul döneminde Hz. Peygamber'i veya sahabenin ileri gelenlerini müstenbitler (hüküm çıkarma uzmanı) olarak tanımlarken, bizlere de ilgili konu uzmanlarını veya yetkilileri işaret etmektedir. Mesaj açık ve nettir, toplumun her bir bireyi toplumu ilgilendiren ve bilhassa toplumun infial yaşayabileceği hassas konularda sorumluluk altında olduğunu unutmamalı ve bir haberi teyit ettirmeden paylaşmamalıdır.

Nisâ sûresinin 83. âyetinin muhtevasının benzer şekilde Uhud Savaşı́nı konu edinen Âli İmran sûresinde de yer aldığını görebilmekteyiz. Kur'ân, Uhud Savaşı sonrasında vuku bulan ve özellikle toplumda hassasiyetin had safhada olduğu dönemde birey(ler)in topluma karşı sorumlulukları bağlamında bilgi aktarımında dikkatli olması ve toplumun da ilgili haberin psikolojik harp gayesi taşıdığı hakikatinin bilincinde olması gerektiğine ve dair somut bir örnek zikreder. Âli İmran sûresinin 172-175. âyetleri ${ }^{30}$ savaştan sonra psikolojik harp tekniği ile toplumu korkutma gayesi taşıyan eylem ve söylemlerin devreye alındığına ve bunlara

27 Muhammed b. Ali b. Muhammed eş-Şevkânî, Fetḥu'l-ḳadîr: el-câmiu beyne fenniyyi'r-rivâyeti ve'd-dirâyeti min i'Imi't-tefsîr, thk. Abdurrahman Umeyra (y.y: Dâru'l-Vefâ, ts.), 1/782

28 Mâturîdî, Tevilâtu ehli's-sünne,3/276; Ebu'l-Hasan Ali b. Muhammed b. Habîb el-Mâverdî, en-Nüket ve'l-'uyûn: Tefsîru'l-Mâverdî, thk. Abdulmaksûd b. Abdurrahîm (Beyrut: Dâru'l-Kutubi'I-'Ilmiyye, ts.), 1/511;

29 Hayrettin Karaman v.dğr., Kur'an Yolu Türkçe Meal ve Tefsir (Ankara: DiB Yay., 2007), 2/104.

30 Illgili âyetler mealen şöyledir: "Bunca yara aldıktan sonra yine Allah'ın ve peygamberin çağrısına koşanlar var ya işte onlardan bu güzel davranışta bulunan ve karşı gelmekten sakınanlar için de büyük mükâfat vardır. Birtakım insanlar onlara, "Insanlar size karşı asker toplamışlar, onlardan korkun" dediler de bu, onların imanlarını arttırdı ve "Allah bize yeter, O ne güzel vekildir!" diye cevap verdiler. Bunun üzerine Allah'ın lütuf ve keremiyle kendilerine hiçbir fenalık dokunmadan geri döndüler Allah'ın rızasına da uymuş oldular. Allah büyük lütuf sahibidir. Bakın, bu şeytan ancak kendi yandaşlarını korkutur. Mümin iseniz onlardan korkmayın, benden korkun." 
karşı dikkatli davranılmasına dikkat çeker. Haddizatında müminlerin bu girişimlere prim vermediğinin de altı çizilir. ${ }^{31}$

Rivayetlerin aktardığına göre Mekke müşrikleri Uhud Savaşı sona erdikten sonra Mekke'ye dönerken Rahvâ denilen bölgede Müslümanları topluca yok etme imkânı edinmişken bu fırsattan istifade etmediklerine pişman olup, Medine'ye bir baskın yapmayı planlarlar fakat buna cesaret edemezler. Nitekim Hz. Peygamber (a.s) böyle bir ihtimali ön görerek savaştan yorgun ve bitkin bir halde çıkmış olmalarına rağmen yaklaşık 200 kişi ile müşrik ordusunu Hamrâulesed mevkiine kadar takip eder. Orada üç gün beklerler, tehlikenin geçtiği kanaatine varınca da tekrar Medine'ye dönerler. Ne var ki, Müslümanları tümüyle hezimete uğratamadığı için pişman olan Ebu Süfyân bazı casuslar göndererek Medine'deki müminleri yok etmek için ordular toplandığı şeklinde yalan haberler yaymalarını ve böylelikle toplumda psikolojik bir etki oluşturmayı amaçlar. Kur'ân ise bu dezenformasyona işaret ederek durumun öyle olmadığını ve söz konusu casus/ casuslara $^{32}$ ve onların yalanlarını gündemde tutmaya çalışan münafıklara inanılmamasına dair enformasyon (hakikati beyan) yapar. ${ }^{33}$

\subsection{Dezenformasyona Karşı Enformasyon (Yalan Bilginin Reddi ve Doğru Bilginin Aktarımı)}

Kurân nüzul sürecinde bazı dönemlerde meydana gelen ve mağdurların var olduğu bazı olaylar bağlamında dezenformasyona (yalan haber/iftiralara) karşılık enformasyon işlevini yerine getirerek mağduriyetleri gidermiştir. Bu bağlamda bir makalenin sınırlarını aşmamak için örneklerin tümünü zikredebilmek mümkün değildir. Dolayısıyla de söz konusu olaylar ve Kur'ân'ın rolü bazı örneklerle sınırlandırılacaktır. Özellikle ilk iki başlık Hz. Peygamber'e düşmanlığı ile meşhur olmuş bir münafığın söylemlerini reddeden ve masum insanları temize çıkaran ayetleri konu edinmektedir.

\subsubsection{Kitlelerin Tahrikine Dair Söylemin Reddi}

Bu başlık altında en küçük bir fırsattan istifade ederek toplumları manipüle etmeyi gaye edinen bir kişinin tavrına Kur'ân'ın müdahalesini ve masum bir sahabenin dile getirdiği doğru bir bilginin konunun muhatabı tarafından reddedilmesi üzerine sahabenin temize çıkarılması olayını ele alacağız. Rivayetlerin aktardığına göre Müreysî Gazvesi'nde biri Ensar diğeri Muhacir taraftarı iki kişi arasında su yüzünden kavga çıkar. Olayın fâilleri taraftarlarını da olayın içerisine katınca bir anda birçok kişinin içerisinde bulunduğu bir çatışma ortamı meydana gelir. Hz. Peygamber (a.s) kitlelerin tahrikine sebebiyet verecek cahiliye döne-

31 Âli İmrân, 2/175.

32 Mâverdî, en-Nüket ve'I-'uyûn, 1/438; Beġavî, Meâlimu't-Tenzîl, 2/138; Şevkânî, Fethu'l-kadîr, 1/651-652; Ebû Hayyân, el-Bahru'l-muhît, 3/125; Ebû Hayyân, ayetteki şeytanın Naîm b. Mes'ûd veya Ebû Sufyân olabileceğine ek olarak "zâlikum" ibaresinde cemi/çoğul zamirinin bulunması bağlamında birçok casus olabileceğini söyler. Bunlar toplumu korku veya endişeye sürüklemek göreviyle iş başındadır.

33 Mâverdî, en-Nüket ve'I-'uyûn, 1/438; İbn Atiyye, el-Muharreru'I-vecîz, 1/544; Beydâvî, Tefsîru'I-Beydâvî, 1/49. 
mine ait propaganda ve söylemlerden rahatsızlığını açıkça beyan ederek olayı yatıştırır. Ne var ki Hazrec kabilesinin reisi Abdullah b. Übeyy olayı rencide ve tahkir edici cümlelerle provoke etmeye devam eder. Muhacirlerin kendi topraklarında kendilerine kafa tuttuklarını ifade ederek durumu; "Köpeğini semirt, seni yesin" şeklinde çirkin bir teşbih ile tanımlar. Devamında da bu sonuca kendilerinin sebebiyet verdiklerini ve Hz. Peygamber'in (a.s) etrafında bulunanlara yardım edilmemesini söyledikten sonra Medine'ye varınca güçlü olanın (yani kendilerinin) zayıf olanı (muhacirleri) şehirden çıkaracaklarını ekler. ${ }^{34}$ Söylenen bu çirkin ifadeleri duyan ve o dönemde henüz genç bir sahâbî olan Zeyd b. Erkam itiraz edince Abdullah b. Übeyy onu azarlar. Durum kendisine intikal eden Hz. Peygamber (a.s) olayın alevlenmemesi için orduyu uzun bir süre hareket halinde tutar. Müsait bir zaman ve zeminde İbn Übeyy'i çağırtıp kendisine ulaşan bilgiyi aktarıp hakikatini sorunca İbn Übeyy yemin ederek öyle bir şey söylemediğini dile getirir. Bu cevap üzerine konuşulanları işittiğini söyleyen Zeyd b. Erkam aleyhine bir durum oluşur ve zan altında kalır. Ne ki, Münafikûn Sûresi'nin ilk 8 ayeti yukarıda zikredilen olaylara dair bir enformasyon (hakikatin beyanı) yapar ve İbn Übeyy'i tekzip ederken, Zeyd b. Erkam'ın masumiyetini dile getirir ve onun haklıığını ortaya çıkarır. ${ }^{35}$

İlahi metnin buradaki müdahalesinin sadece bir şahsın söylemlerinin reddi bağlamında okunması isabetli bir sonuç vermeyebilir. Zira bu kişi toplumsal bir konu bağlamında kitleleri tahrik etmek istemektedir ve eyleminin amacı bireysel değildir, Medine'deki tüm toplumu ilgilendirmektedir. İlgili kişinin söylemlerinde iki taraf vardır. Bir tarafta "öteki" olarak tanımlanan ve çirkin teşbihlerle tahkir edilen Ensar topluluğu vardır. Diğer tarafta ise "ben/biz" olarak tanımladığı bir kitle vardır ve bu iki topluluk arasına fitne ekme gayreti apaçık bir şekilde ortaya çıkmaktadır. ${ }^{36}$ Münafıkûn Sûresi'nin ilgili ayetleri sadece ismi bahis kişinin söylemlerini reddetmekle yetinmemekte, toplumun "her iki tarafının" bu konuda dikkatli olması gerektiğinin de altını çizmektedir.

Kur'an mümin, münafık veya kâfir olması fark etmeksizin nüzul döneminde çok geniş kitlelere ulaşabilmek yönüyle günümüz sosyal medyası mesabesinde bir enformasyon yapmış olmaktadır. Hakikati ayan beyan bir mahiyette dile getirirken, yalan ve maksatlı söylemlere dikkat çekerek muhatapları uyarmaktadır. Aynı zamanda konunun faili olan kişiyi de tahkir ve tezyif etmekte ve "Bağışlanmaları için Allah'a dua etmişsin veya etmemişsin onlar için birdir. Allah onları asla bağışlamayacaktır"37 ayetiyle o ve onun gibilere uhrevi bir müeyyide uygu-

34 el-Münâfikûn, 63/7-8.

35 Taberî, Câmiu'I-beyân, 22/657; Vâhidî, el-Vasitt, 4/304; Ebu'l-Fazl Celâleddîn Abdurrahman es-Suyûtî, ed-Dürrü'lmensûr fi't-tefsîri bi'l-me'sûr, thk. Abdullah b. Abdulmuhsin et-Türkî (Kahire: Merkezu Hicr li'l-Buhûs, 2004), 14/500; Ebu'l-Fidâ İsmail b. Ömer İbn Kesîr, Tefsîru'l-Kur'âni'I-'Azîm, thk. Sâmî b. Muhammed es-Sellâme (Riyad: Dâru Tayyibe li'n-Neşr, 1997), 8/127.

36 Râzî, Mefâtîhu'l-gayb, 30/17; İbn Âşûr, et-Tahrîr ve't-tenvîr, 28/246.

37 el-Münâfikûn, 63/6. 
lamaktadır. Mezkûr ayetlerin hususi bir nüzul sebebi olsa da benzeri kişilik, gaye ve söylemlerin her zaman ve zeminde var olabileceğine dair evrensel vurgusunu da görmek gerekir. ${ }^{38}$ Çalışmamızı ilgilendiren yönü de burada tebarüz etmektedir. Günümüzde sosyal medyada bazı kişi veya grupların kitlelerin hassas olduğu konularda dezenformasyon ve yalan haber üretmekten hiç çekinmediklerini görebilmekteyiz. Nitekim çalışmanın başında da buna dair örnekler zikredilmiştir.

\subsubsection{Kitleleri Psikolojik Olarak Pasifize Etme Gayretinin Eleştirisi}

Bir üst başlıkta Müslümanlar arasında huzursuzluk çıkarmaya çalışan münafık tiplemesine dair ayetleri ele almıştık. Bu başlıkta da yine faillerinin benzer olduğu bir olguyu ele alacağız. Özellikle Müslümanların büyük fedakarlıklar ortaya koyduğu Tebük Savaşı öncesinde Medine'deki münafıkların gayretlerinin ele alındığı Tevbe Sûresinin 86-99. âyetleri müminleri psikolojik olarak yıldırma çalışmalarına karşı da aktif bir tepkisel söylem ortaya koyar. Bu söylemin ilki, ekonomik ve fiziksel imkânı olduğu halde müminlerle bir arada olmaktan geri duran münafık tipolojilere karşıdır. Bu kişiler Müslümanların yanında olmamakla yetinmemekte, psikolojik bir harekatın içerisinde de aktif rol almaktadırlar. Savaşın hemen öncesinde müminleri psikolojik olarak yıldırmak isteyen bu zümre bunu iki temel argüman ile tahkim etmek gayretindedir. Bu argümanların ilki, şartların zorluğunu bahane ederek müminlerin moral ve motivasyonunu bozmaktır. 'Bu sıcakta sefere çıkmayın' diyen ve aslında iyi niyetle bunu dillendirdiğini söyleyen münafıklara Allah, 'cehennemin ateşinin daha sıcak olduğunu' söyleyerek cevap vermektedir. Bu ayetin maksadı hakiki manayı ifade etmek değildir. Aksine muhataplara karşılaşacakları cezaya dair betimleme yapmaktır. ${ }^{39}$ Yaptıkları eylemin sonucunun bilincinde olmalarını ifade edilirken, müminlere de fedakarlık yapmaları için teşvik vardır.

Münafıkların ikinci argümanı da 'tahkir ve alay ederek' moral bozmaktır. Bu süreçte elindeki imkânları seferber eden müminlerin eylemlerinin alaylı bir üslup ile değerlendirildiği görülmektedir. Özellikle imkânı iyi olan müminlerin büyük bağışları için 'gösteriş için infak edildiğini' söyleyen bu münafıklar, imkânları sınırlı olduğu için az miktarlar ile katkıda bulunanları da tahkir etmekten geri kalmıyorlardı. 'Muhammed'in onların küçücük katkıları' ile güçlü bir devlete kafa tutmak gibi garip bir hal içinde olduğunu söyleyerek alay etmekteydiler. ${ }^{40}$ Kur'ân bu eylemleri ilgili sûrede ele alarak münafıklara hem cevap vermekte hem de müminleri yücelterek ${ }^{41}$ gönüllerini ferahlatmaktadır. Bu yönüyle Kur'ân'ın sosyopsikolojik bir rol de üstlendiğini söylemek mümkün olacaktır. Sadece müminleri manevi olarak tahkim ve teşvik etmemekte, münafıkların da hem uhrevi hem

38 İbn Âşûr, et-Tahrî̀r ve't-tenvîr, 28: 243-244; Karaman, Kuran Yolu, 5/567-568.

39 Taberî, Câmiu'I-beyân, 11/602; İbn Atiyye, el-Muharreru'l-vecîz, 3/65-66; Ebû Ca'fer Muhammed b. Hasan et-Tûsî, et-Tibyân fì tefsîri'l-Kur'ân, thk.Ahmed Habîb el-Âmilî (Lübnan: Dâru İhyâi't-Turâsi'l-'Arabî, ts.) 5/270;

40 Taberî, Câmiu'l-beyân, 11/588; İbn Atiyye, el-Muharreru'l-vecîz, 3/63; Tûsî, et-Tibyân fî tefsîri'l-Kur'ân, 5/267; Ebû Ali el-Fadl b. Hasan et-Tabersî, Mecmeu'I-beyân fî tefsîri'l-Kur'ân (Beyrut: Dâru'I-'Ulûm, 2005), 6/127.

41 et-Tevbe, 9/88, 89, 92. 
de dünyevi cezalara çarptırılması gerektiğini söyleyerek manevi bir baskı uygulamaktadır. Onların asla bir daha müminlerle herhangi bir savaşa çıkmamalarının söylenmesi ${ }^{42}$ toplumsal bir baskı oluşturmuştur. Diğer taraftan onları 'pislik' olarak tanımlaması ve varacakları yerin cehennem olacağının ifadesi de uhrevi bir müeyyidedir. ${ }^{43}$

\subsubsection{Toplumun Bireylerin Haklarına Karşı Sorumluluğu}

İlahi metin sadece bireyin toplum karşı değil, toplumun da her bir bireyine karşı sorumluluk üstlenmesi gerektiğini beyan eder. Aksi takdirde toplum içerisinde yanlış olan eylem ve söylemler kolayca kendilerine meşruiyet zemini bulabilecektir.

\subsubsection{Iffk Hâdisesi}

Ifk hâdisesi bağlamında yapılmış güncel çalışmaların epeyce yekûn tuttuğunu ifade etmek gerekir. ${ }^{44}$ Biz bu konuya dair çalışmamızı ilgilendirdiği kadarıyla bilgi vermekle yetineceğiz. İfk hadisesi rivayetlerden edindiğimiz kadarıyla yine Müreysi Gazvesi bağlamında gündeme gelmiştir. Hz. Peygamber'in Müreysî (Benî Müstalik) Gazvesi'nde yanında götürdüğü muhterem eşi Hz. Aişe ihtiyacını görmek için ordunun mola verdiği yerden ayrılır. Dönerken gerdanlığını düşürdüğünü fark eder. Onu aramak için geri döndüğünde geç kalır ve ordu hareket ettiği için geride kalır. Safvan b. Muattal isimli sahâbî ordunun arkasından gelerek Hz. Aişe'yi tek başına bulur, devesine bindirerek orduya yetiştirir. Bu olay üzerine yine Abdullah b. Übeyy'in başını çektiği bir grup Hz. Peygamber'in (a.s) temiz eşine ve ismi geçen sahâbîye zina iftirasında bulunurlar. Olay dilden dile dolaşarak kısa sürede tüm herkes tarafından bilinir hale gelir. Hz. Aişe de bir vesileyle olaydan haberdar olur ve babasının evine gitmek için $\mathrm{Hz}$. Peygamber'den izin ister. Hz. Peygamber (a.s) bu olaydan çok etkilenir ve bir çözüm yolu bulmak için hem mescitte dile getirir hem de bazı isimlerle özel istişarelerde bulunur. Nur sûresinin 11-20. âyetleri bu olay üzerine iner. Hz. Aişe ve iftirada ismi geçen sahâbînin temiz olduklarını ve bu olayın fâillerinin cezalandırılmasını beyan eder. $^{45}$

Ifk hadisesine dair ayetler bir arada okunduğu zaman, Kur'ân'ın bu olay bağlamında birkaç hususu ön plana çıkardığı görülür. Öncelikle bu iftirayı ilk ortaya çıkaran elebaşı ve bu kirli propagandaya aracılık yapanlara yapılan sert bir uyarı

42 et-Tevbe $9 / 81-84$.

43 Taberî, Câmiu'I-beyân, 10/209-211; İbn Atiyye, el-Muharreru'I-vecîz, Sevkânî, Fethu'l-kadîr, 2/445-446

44 Ifk hadisesi bağlamında yapılmış birkaç çalışmayı şöyle zikredebiliriz; Seyfullah Kara, "ifk Olayının Etkileri ve Olayla İlgili Ortaya Konan Tavırlar", Atatürk Üniversitesi Illahiyat Fakültesi Dergisi, 15/1 (2001), 343-382; Ali Aksu, "Iffk Hadisesi ve Sonuçlarının Ifffet Açısından Değerlendirilmesi", Din ve Hayat: İstanbul Müftülüğü Dergisi, 19/1, (2013), 84-92; Harun Şahin, "Kuran Perspektifinden İnsan Onuru, Mahremiyet ve Ifk Hadisesi", Din Gelenek ve Ahlak Bağlamında Mahremiyet Algıları Sempozyumu (27-29 Mart 2015), Samsun: 2016, 503-515.

45 Taberî, Câmiu'l-beyân, 17/218-221; İbn Kesir, 6/27; Suyûtî, ed-Dürrü'l-mensûr, 10/687; 
vardır. Ayrıca kirli kampanyada rol üstlenenlerin her birisinin iftiranın yükünü yükleneceğini, olayın fitilini ateşleyen kişiye ise büyük bir azabın olacağını dile getirir. ${ }^{46}$ Âyetin aktüel mesajı açıktır. Toplumda herhangi bir bireyin namusuna, şerefine ve izzetine leke sürecek eylem ve söylemlerde bulunan kişilere ve bu kötü eylemlere aracılık yapanlara cezai müeyyide uygulanmalıdır. ${ }^{47}$ Böylelikle toplumdaki her bir birey kitlelere mal olacak bir bilgiyi paylaşırken veya ona aracı olurken dikkatli davranması gerektiği, eğer araştırmadan bir bilgi paylaşımı yaptıysa onun sorumluluğunu da yükleneceği bilinciyle hareket edecektir.

İlgili ayetlerin bireye matuf yönünün yanı sıra topluma matuf mesajları da vardır. Toplumdaki her bir bireyin teker teker sorumluluğu olduğu gibi, toplumun/toplumların da ortak bir ahlaki duruş/yönelim ortaya koymak yönüyle sorumluluğu vardır. Nitekim ilgili ayetlerde Kur'ân müminlerin davranışının nasıl olması gerektiğini de ifade eder. Bu iftira işitildiğinde müminlerin; “Bunu konuşmak bize yakışmaz, Allah'ım sen yücesin, bu apaçık bir iftiradır"48 demeleri gerektiğini beyan ederek toplumsal duruşun nasıl olması gerektiğini de beyan eder. Ne yazık ki bu ayetin bir öncesinde müminlerin bu sınavdan başarı ile çıkamadığı, "iftirayı dilden dile dolaştırdıkları, bilgi sahibi olmadıkları bir konuyu dillerine doladıkları ve bunu da önemsiz saydıkları"49 şeklinde bir sosyo-psikolojik tahlil yapılmaktadır. Ebu'l-'Alâ el-Mevdûdî (ö. 1979) toplumun duruşu ve ahlâkî edinimine dair önemli tespitlerde bulunmuştur. Mevdûdî'nin yorumları mücmel bir mahiyette şöyle zikredilebilir. Öncelikle, eğer bir kimse, bir kadın ve bir erkeğin yalnız kaldığında hemen günah işleyeceğini iddiasında bulunacak oluyorsa, bu suçlama iki varsayım daha doğurur. Toplumdaki her bir birey böylesi nadir fırsatlardan hemen faydalanacak ve günah işleyecek demektir. Çünkü daha önce karşıt cinsten birisiyle bu şartlarda bulunmamıştır. İkincisi, bu toplumda benzer durumlarla karşılaşıldığında günahtan kaçınabilecek hiçbir kadın ve erkeğin bulunmadığı anlamına gelir. Fakat olgunun daha da ağır yönü, zina ile suçlanan her iki kişinin birbiriyle içli dışlı olan aynı toplumun üyesi olmasıdır. Unutulmamalıdır ki, geride kalan kadın eştir, kardeştir, annedir, komşudur, dostun namusudur. Bu şartlarda sorun daha ağır ve ciddi bir mahiyete evrilmiş olur. Çünkü bu toplumda herhangi bir birey komşusunun kızını, eşini, dostunun namusunu yolda yalnız bulursa hemen onunla ilgili kötü bir düşünceye kapılır ve onu kirletmeye yeltenir. Oysa erdemli toplumlarda hiçbir soylu kişi bunu asla düşünmez. Eğer bu kadın canlarından daha azizi bildikleri Hz. Peygamber'in (a.s) eşi ve kendi öz anneleri gibi haram olan ümmehât-ı mümininden ise zina iftirasında bulunan kişilerin ve suçlamayı mümkün görenlerin yalnızca kendilerinin değil, ait oldukları toplumun

\footnotetext{
46 en-Nûr, 24/11.

47 Akpınar, 'İslam Hukuku Açısından Sosyal Medya', 498-500; Çalık, "Beden, Mesken ve Bilgi Mahremiyeti Açısından Sosyal Medyadaki Tasarrufların Fıkhî Açıdan Değerlendirilmesi", 38-40.

48 en-Nûr, 24/16.

49 en-Nûr, 24/15.
} 
tümünün ahlâkı hakkında nasıl perişan ve zavallı bir görüşe sahip oldukları ortaya çıkmaz mı? $?^{50}$

Ifk hadisesi bağlamında Kur'ân hem bireysel hem de toplumsal sorumluluklar bağlamında bizlere mesajlar vermektedir. Öncelikle, bir kişi paylaştığı bir bilginin kaynağını iyice öğrenmeli, paylaştığı bilginin sonuçlarını da ön görerek paylaşımda bulunmalıdır. Gerekirse yaptığı eylemin karşılığında cezai müeyyide ile karşılaşacağını bilmelidir. Hadise bağlamında dile getirilen toplumsal sorumluluk ise toplumun tümünün muhatap olduğu ortak yanlıştır. Toplum, bir bireyin mahremiyetinin, namusunun ve onurunun söz konusu olduğu bir konuda sorumsuzca davranamaz. Hassaten kişinin namus, şeref ve izzetine matuf iftira kampanyalarında doğrudan yana taraf olmalıdır. Konuyu aktüel olarak değerlendirecek olursak, kitlelere anlık bilgi ulaşımına vesile olan sosyal medya paylaşımlarında toplumun yanlışa karşı ortak duruş/eylem sergilemesi gerektiğini söyleyebiliriz. Eğer toplumdaki bireyler sorumluluğunun farkında olur ve toplum yanlışın/yalanın/iftiranın karşısında duracak olursa o toplumda yanlış olanın kendine zemin bulması mümkün olmayacaktır. Haddizatında bu konuya matuf birkaç güncel çalışma Kur'ân'ın dikkat çektiği 'toplumsal yönelime' dair etkileyici örnekler zikrederek olayı tasrih etmiştir. Maalesef yanlışa tepki koyarak yanlışın önünü alması gereken toplum üyeleri aksine yanlışın meşruiyet kazanmasına zemin hazırlamaktadırlar. ${ }^{51}$

\subsubsection{Gizli Planların İfşası}

Kur'ân'ı Kerîm nüzul sürecinde bazı kirli planların esas gayesinin ne olduğunu ifşa ederek Hz. Peygamber'in (a.s) hataya düşmemesini sağlamıştır. Bu bağlamda iki tane örnek ile iktifa edeceğiz. İlki bireysel bir girişim olarak ifade edilebilecek iken, diğer planın gayesi kitleseldir ve çok boyutlu bir yönü vardır. Her iki olayın zahirde samimi bir gayesi var gibi görünmektedir. Ama aslında olayın perde arkası kirli ilişkiler ağından oluşmaktadır.

50 Ebu'l-'Alâ el-Mevdûdî, Tefhimu'l-Kur'ân, çev. Muhammed Han Kayani (İstanbul: İnsan Yayınları, 2000), 3/506; Benzer yorum için bk. Muhammed İzzet Derveze, et-Tefsîru'l-hadîs: tertibu's-süver hasebe'n-nüzûl, (Kahire: Dâru İhyâi'I-Kutubi'l-Arabi, 1383/1964), 6/329; Süleyman Ateş, Yüce Kur'an'ın Çağdaş Tefsiri (İstanbul:Yeni Ufuklar Neşriyat, 1988), 6/168.

51 Şiddet, cinsellik ve ahlaksız itiraflar gibi aslında mahremiyet çerçevesinde olması gereken olgular haberin reyting değerini arttırdığı için daha fazla paylaşıı olmuştur. Toplumsal ahlaki değerlerin normal şartlar altında kabul edemeyeceği bazı sosyal medya paylaşımları bireylerin 'beğenilme/göz önünde olma' güdüsünün etkisiyle zamanla normalleşmeye ve hatta 'olması gereken' bir durum haline dönüşebilmektedir. Konuya dair tafsilatlı veri ve örneklemler için bk. M. Raşit Akpınar, 'İslam Hukuku Açısından Sosyal Medya', 493-509; Nilüfer Sena Çalık, Beden, 'Mesken ve Bilgi Mahremiyeti Açısından Sosyal Medyadaki Tasarrufların Fıkhî Açıdan Değerlendirilmesi' Türk Akademik Araştırmalar Dergisi, 3/1, (Haziran, 2018), 25-44; Mustafa Derviş Dereli, 'Gözetim Toplumunda Sosyal Medya ve Mahremiyetin Dönüşümü', Din, Gelenek ve Ahlak Bağlamında Mahremiyet Algıları Sempozyumu, Samsun 2016, 538-540. 


\subsubsection{1. 'Öteki' Üzerinden Masumun Suçlanma Çabasının İfşası ve Eleştirisi}

Rivayetlerin aktarımına göre Rifâa b. Zeyd isimli sahâbî, yabancı tacirlerin Medine'ye getirdikleri has undan bir miktar satın alıp unu içinde silâhlarının da bulunduğu evin sofasına koyar. Übeyrık ailesinden biri gece sofaya girip unla birlikte Rifâa'nın silâhlarını da çalar. Rifâa durumu tetkik ettirip Übeyrık ailesine ulaşınca onlar suçu Lebîd isimli masum bir Müslümanın üzerine atarlar. Lebîd olaya sert bir tepki verince onu suçlamaktan vazgeçerler. Yapılan araştırmalar sonucunda hırsızın Übeyrık ailesinden olduğuna kesin kanaat getirilince olay Hz. Peygamber'e intikal eder ve o da gerekeni yapacağını beyan eder. Ne var ki Übeyrık ailesi durumu öğrenince bir plan kurarak kendileri lehine konuşacak birini Resûlullah'a gönderip iftiraya uğradıklarını, ortada bir delil bulunmadığı halde Katâde tarafından hırsızlıkla suçlandıklarını bildirirler. Hz. Peygamber (a.s); "Bana Müslüman ve suçsuz oldukları söylenen kimseleri, elinde bir delil olmadığı halde hırsızlıkla suçladın!" diyerek Katâde'ye serzenişte bulunur. Katâde olup bitenden son derecede üzüntü duyarak amcasına gelip durumu anlatır ve işlerinin Allah'ın yardımı ile çözülebileceğini beyan eder ve bunun üzerine Nisa sûresinin 105. âyeti iner. ${ }^{52}$

Diğer rivayete göre Benî Zafer kabilesinden Tu'me b. Ubeyrik isminde birisi Ensar'dan birinin zırhını çalıp bir Yahudi'nin evine gizlenir. Hırsızlıkla ilgili soruşturma derinleştirilince zırhın sahibi meseleyi Hz. Peygamber'e (s.a) götürüp Tu'me'den şüphelendiğini söyler. Fakat suçlu olan Tu'me'nin akrabaları ve Benî Zafer kabilesinden birçok kişi iş birliği yapıp suçu masum bir Yahudi'nin üzerine yıkmaya çalışırlar. Yahudi masum olduğunu söyleyince Tu'me'nin akrabaları Yahudi'yi suçlamayı sürdürerek; "Hakkın düşmanı olan, Allah ve Rasûlü'ne inanmayan bir Yahudi'nin sözüne güvenilmez. Oysa biz Müslümanız ve güvenilir kişileriz, o halde bizim sözümüze inanılmalı" diyerek kendilerini savunurlar ve Hz. Peygamber (a.s) ilgili kişilerin sözlerinden etkilenir. Tu'meyi beraat ettirip Yahudi'yi mahkûm edeceği sırada ilgili ayet iner ve Hz. Peygamber'in hainlerden yana tavır almaması gerektiğini beyan eder. ${ }^{53}$

Nisa Sûresi'nin 105. ayetini tefsir eden Mevdûdi Kur'ân'ın Hz. Peygamber'in şahsında bizlere de mesajlar verdiğini ifade eder. Eğer Hz. Peygamber (s.a) 'öteki' olarak tanımlanan fakat masum olan Yahudi aleyhine karar vermiş olsaydı bu durum İslam düşmanlarına etkili bir propaganda aracı olacaktı. İlgili âyet ve öncesindeki ayetler (105-115. ayetler) kendi kabilelerinden suçlu olan kişinin suçunu gizlemeye çalışan Müslümanları kavmiyetçilikleri nedeniyle sert bir şekilde tazir etmektedir. Diğer taraftan bütün Müslümanlara kavmiyet ve kabile endişelerinin adaleti engellememesi gerektiği öğretilmektedir. ${ }^{54}$

52 İbn Kesîr, Tefsîru'I-Kur'âni'l-'Azîim, 2/405-406; Suyûtî, ed-Dürrü'l-mensûr, 4:679-680.

53 Taberî, Câmiu'l-beyân, 7/458; Suyûtî, ed-Dürrü'l-mensûr, 4:682.

54 Mevdûdî, Tefhimu'l-Kur'ân, 1/403; Ateş, Yüce Kur'an'ın Çağdaş Tefsiri, 2/364. 
Nisâ Suresinin 105. âyetinde Kur'ân yalan ve yanlış olan bir durumun hakikatini izhar ederek enformasyon rolünü üstlenmiş; diğer taraftan muhataplarına evrensel bir ahlaki ilkeyi öğretmiştir. Bu ilke, kişilerin bir olayı asla 'öteki' üzerinden okumaması gerekliliğidir. Illgili âyette suçlu olmasına rağmen etnik/dini aidiyet üzerinden tanımlama yapan ve masum rolüyle kendilerini savunmaya çalışan kişilerin hain olduğu beyan edilmekte ve masumiyet rolünün arkasında kirli bir planın var olduğu deşifre edilmektedir. Bilhassa ilgili rivayetin ikincisinde kendisini Müslüman olarak tanıtan kişiler masum bir insanı sadece 'öteki' olması sebebiyle potansiyel suçlu/yalancı olarak lanse etmeye çalışmışlardır. Allah ise ilgili ayette kendilerini Müslüman olarak tanımlayan bu kişileri 'hainler' olarak tavsif etmiştir. Maalesef büyük kitlelere ulaşabilme aracı olan sosyal medyada çoğu insan bir haberin içeriğini hiç araştırmaya ihtiyaç duymadan sadece 'ötekini' tanımlaması sebebiyle sorumsuzca paylaşabilmektedir. Oysaki kişinin masumiyetini belirleyen öge 'bizden' veya 'ötekinden' olması değil, olgu veya hakikattir. Binaenaleyh, evrensel ve aktüel bir okumaya tabi tuttuğumuzda Kur'ân'ın bize/muhataplarına 'öteki' üzerinden yapılan tanımlamanın riskler barındırdığına dair sosyal medya sorumluluğu öğrettiğini söylemek yanlış olmayacaktır. Nitekim çalışmamızın girişinde ülkemizde yaşanan bazı olayların siyasi ve politik çıkarlar için bilinçli bir şekilde 'etnik kimlik ve öteki' üzerinden değerlendirmeye ve böylelikle toplumda çatışma ortamını tetiklemeye çalışan bazı yapılara dair örnekler zikredilmişti.

\subsubsection{Kutsal Mekânın İstismarının Iffşası}

Çalışmamızda ele alacağımız son âyetler yine önemli münafıkların ele başlığını yaptığı Mescid-i Dırar olayı bağlamındadır. Söz konusu mescidin inşasının fikir babası cahiliye döneminde rahip olan Ebu Âmir'dir ve bu kişi aynı zamanda münafıkların reisi Abdullah b. Übeyy b. Selûl'ün de yakın akrabasıdır. Bu isimler Hz. Peygamber Medine'ye gelmeden önce Medine'de yönetimi devralmayı planlamaktaydılar. Fakat Hz. Peygamber'in hicret ederek Medine'ye yerleşmesi ve bilahare Müslümanların günden güne güçlenmeleri bu kişileri rahatsız etmekteydi. Konunun dikkat çekici yönü ise ismi geçen kişilerin Müslümanların aleyhindeki propaganda metodunu süreçle birlikte değiştirmeleri ve buna da kutsalı araç edinmeleridir. Zira Hz. Peygamber'in (a.s) "Ebû Âmir el-Fâsık" dediği bu kişi Bedir ve Uhud gazvelerinde müşrik saflarında bizzat bulunarak aktif bir rol almışken, Mekke'nin fethinden sonra Tâif'e sığınmıştır. Huneyn Gazvesi ve Tâif seferinden sonra Suriye'ye giden Ebû Âmir Medine'deki münafıklar ile bağlarını devam ettirmiş; gönderdiği mektuplarda Bizans valisi ile görüştüğünü ve Müslümanları Medine'den çıkartacağını ifade etmiştir. Fakat bu gayenin gerçekleştirilebilmesi için münafıkların plan ve programlarını görüşebilecekleri ve aynı zamanda da dikkat çekmeyecek bir mekâna ihtiyaç duyduklarını beyan eder. Bu planın sonucu olarak da Mescid-i Dırar'ın yapımına karar verilir. Mescidin inşasının gayesi de zahirde tamamen masumane bir gerekçe üzerine bina edilmiş- 
tir. Münafıklar, Mescid-i Nebevî'nin uzak olması, hastalık, yağmur ve mesafe gibi makul ve makbul gerekçelerle mescidin inşa edildiği ifade edilmiştir. Ama asıl gaye Ebû Âmir ile kolay ve rahatça istişare edebilecekleri bir casusluk merkezi inşa etmekti. ${ }^{55}$

Hz. Peygamber, Medine dışında Tebük Seferi'nin son hazırlıklarıyla uğraşırken münafıklardan bir heyet gelip yağmurlu ve soğuk kış gecelerinde hasta ve özürlü olanların namaz kılması için bir mescit inşa ettiklerini ve kendilerine namaz kıldırarak burayı ibadete açmasını isterler. Hz. Peygamber (a.s) savaşa çıkmak üzere olduğunu, dönüşte orada namaz kıldırabileceğini ifade eder. Tebük dönüşü ordusuyla birlikte Zûevan'da konakladığında bazı münafıklar gelerek Hz. Peygamber'i mescide götürüp namaz kıldırmak isterler. Böylelikle zahirde masumane bir gaye ile inşa edilen mescide meşruiyet kazandırılmış olacaktır. Fakat mescidin yapılış gayesi ve münafıkların niyetleri hakkındaki âyetler nâzil olur ${ }^{56}$ ve Hz. Peygamber'in (a.s) bu mescitte namaz kılmaması ifade edilir. İlgili âyetlerde mescidi inşa edenlerin niyetlerinin müminlere zarar vermek, hakkı inkâr etmek, müminlerin arasına nifak sokmak ve daha önce Allah ve Elçisi'ne (a.s) karşı savaşmış olan bir kişiyi beklemek olduğu izhar edilir. Bu kiş̧ilerin gayelerinin iyilik olduğuna dair yemin bile edebilecekleri, halbuki yalancı oldukları vurgulanır; Hz. Peygamber'e Mescid-i Dırâr'da asla namaza durmaması, buna karşılık takva üzerine kurulmuş mescitte (Mescid-i Kubâ veya Mescid-i Nebevî) namaz kılmasının daha uygun olacağı bildirilir. Bunun üzerine Hz. Peygamber (a.s) Medine'ye ulaşınca mescidin yıkılması emrini verir. Münafıklar mescidin yıkılmış olduğunu görünce Allah'ın, sırlarını ifşa ettiğini ve gizledikleri gerçek amacın $\mathrm{Hz}$. Peygamber'e bildirildiğini anlarlar. ${ }^{57}$

Tevbe sûresinin 107 ve 110. âyetlerinde Kur'ân arka plandaki kirli amaçlarını gizleyen münafıkların esas gayesini deşifre ederek münafıkların planını bozmuştur. Bu ayetlerin makalemizi ilgilendiren iki yönü vardır ki birincisi daha önce de ifade ettiğimiz üzere enformasyon/bilgilendirme işlevini üstlenmiş olmasıdır. İlahi metin, ulaştığı geniş kitlelere münafıkların esas gayesini aktarmış olmakla Müslümanların daha dikkatli davranmalarını sağlamıştır. Bir diğer husus münafıkların kirli planları için hiçbir kutsalı istismar etmekten çekinmediklerini izhar etmiş olmaktadır. İlgili ayetlerin aktüel mesajının günümüzde de pratik karşılığının var olduğunu görebilmekteyiz. Özellikle siyasi ve politik gayeler için kutsalın sosyal

55 Taberî, Câmiu'l-beyân, 11/672-675; İbn Kesîr, Tefsîru'l-Kur'âni'l-'Aẓim, 4/210-212; Suyûtî, ed-Dürrü'l-mensûr, 7/523-524.

56 et-Tevbe 9/107-110.

57 Hüseyin Algül, "Mescîd-i Dırâr” Türkiye Diyanet Vakfı İslam Ansiklopedisi (Ankara: TDV Yayınları, 2004), 29:272273. 
medyada rahatlıkla istismar edildiğini görebilmek mümkündür. ${ }^{58}$ Bu bağlamda kendisini samimi bir Müslüman olarak tanımlayan her bir bireyin sosyal medya paylaşımlarına ihtiyatlı yaklaşması gerekmektedir. Özellikle ülkemizde dini bir istismar aracı olarak kullanan ve kitleleri politize etmeye çalışan bazı grupların sosyal medya paylaşımlarına karşı dikkatli olmak gerekmektedir. Zira iyi olduğu zannedilen bir eylemin arkasındaki kirli oyunları fark edebilmek zaman alabilir ve hakikat anlaşıldığında geç kalınmış olabilir..$^{59}$ Aynı şekilde din adına konuşan bireylerin de cümlelerini onlarca kez düşündükten ve tarttıktan sonra ifade etmesi gerekir. Zira maksadını aşan bazı cümlelerin oluşturacağı tahribatı tasfiye etmek zor olabilir. Bilhassa 'dini hassasiyet' bağlamında kurumları itibarsızlaştırma veya ötekileştirmeye matuf söylemlerden, paylaşımlardan ve bunlara aracı olmaktan kaçınmak gerekir. ${ }^{60}$

\section{Sonuç}

Sosyal medya çağdaş dünyada yaşayan bizlerin kendisinden müstağni kalamadığı bir olgudur. Sosyal medyanın en dikkat çekici yönü bir bilginin çok kısa süreler içerisinde milyonlarca kişiye ulaşabilmesidir. Büyük kitlelere kısa sürede ulaşabilmesi yönüyle sosyal medyanın artık uluslararası ve devletlerarası ilişkilerde yadsınamaz bir rolü vardır. Çalışmamızın girişinde örneklendiği üzere artık günümüzde devletler başka devletlerin iç işlerine sosyal medya aracılığıyla rahatlıkla müdahil olabilmekte hatta sosyal medya üzerinden devrim hareketleri başlatabilmektedir. Böylesi bir gücü elinde bulundurduğu bilinen sosyal medya platformları ülkemizde de büyük ekonomik zararlara sebebiyet veren bazı toplumsal olayları açıktan manipüle etmişlerdir.

58 Malatya'da yenisinin yapılması için eskisi yıkılan bir cami 2015 seçimleri öncesinde sosyal medyada politik bir malzeme olarak kullanılmıştır. Konunun dikkat çeken yönü ise, din ve dini söylem ile çok da barışık olmayan sosyal medya platformlarının bu konuyu gündeme taşımış olmasıdır. https://eksisozluk.com/malatyada-avmyapimi-icin-cami-yikilmasi--3800338 (Erişim, 01.10. 2021) https://odatv4.com/siyaset/akpnin-avm-icin-camiyiktigi-ortaya-cikti-1306131200-38545 (Erişim, 01.10. 2021) Yine kutsalın istismar edildiği bir başka sosyal medya paylaşımı 2021 yılında Gaziantep'te yaşanan bir olay üzerine kendine zemin bulmuştur. \#lbadetimeDokunma ismiyle açılan twitter paylaşımında polisin ayakkabı ile girerek camide itikaf yapan samimi Müslümanlara biber gazı ile müdahale ettiği şeklinde provoke eden bir üslup kullanılmıştır. https://www.indyturk. com/node/353931/haber/furkan-vakf\%C4\%B1-\%C3\%BCyelerine-g\%C3\%B6zalt\%C4\%B1-polis-camide-bibergaz\%C4\%B1yla-m\%C3\%BCdahale-etti (Erişim, 01.10.2021)

59 Neredeyse tüm söylemleri politik amaçlara hizmet eden Furkan hareketi ve ülkemizde darbe kalkışmasına yeltenen Fetö hareketinin sosyal medyayı ve özellikle de twitter'ı aktif kullandığı bir vakıadır. Bu hareketlerin söylemlerinin de bazı sosyal medya platformları tarafından özellikle gündemde tutulduğunu da ifade etmek gerekir. Kendilerini eğitim gönüllüleri masum kişiler olarak tanıtan ve \#Dershanemedokunma başlığıyla eğitimi kendisine malzeme edinenlerin gerçek yüzü 15 Temmuz'da ortaya çıkmıştır. https://twitter.com/dershaneiste (Erişim, 01.10.2021)

60 Makalenin bitme aşamasına geldiği zaman diliminde ülkemizde din eğitimi alanındaki payı ve değeri yadsınamayacak olan İmam-Hatip ve Illahiyat fakültelerini itibarsızlaştırmaya yönelik bir söylem toplumun birçok kesiminden tepki almıştır. İlgili kurumlarda yanlış fikir ve söylemleri olan bireylerin var olduğu hakikatini kabul etmekle birlikte toptan reddiyeci bir söylemin de bir o kadar yanlış olduğunu ifade etmek gerekir. İşin daha da kötü olan tarafı, ilgili mümtaz kurumları tazyif eden açıklamaları yapan ve söz konusu açıklamaları destekleyen kişilerin din ve 'milletin imanını kurtarma' adına konuştuklarını ifade etmiş olmalarıdır. Kur'ân, zımnen bizlere sosyal medya ahlakı bağlamında kitlelere mal olacak eylem ve söylemlerin akıl ve izan süzgecinden geçirildikten sonra pratiğe dökülmesini salık vermektedir. İmam-Hatip ve Illahiyat söylemini eleştirisi için bk. https://onder. org.tr/tr/Haber/imam-hatipler-ornek-egitim-kurumlari-hb12664 (Erişim, 07.10.2021) 
Kur'ân özellikle toplumun hassas olduğu zaman dilimlerinde bireylerin herhangi bir bilgiyi paylaşırken sorumlu davranması gerektiğini vurgular. Bilhassa kişinin her duyduğu şeyi hiç araştırmadan başkasına aktarmasının çok büyük sorumsuzluk olduğunu izhar ederken, çözümü de sunar. Çözüm, kişinin duyduğu bir haberi konunun uzmanlarına teyit ettirmesidir. Kur'ân'ın dikkat çektiği bu olgunun günümüzde de sıklıkla gündeme getirildiğine şahit olmaktayız. Sosyal medyada sorumsuzca paylaşılan yalan haberler toplumdaki gerginliği arttırdığı için devletlerin bazı tedbirlere başvurduğunu görebilmekteyiz. Özellikle hassasiyet arz eden bazı konularda birtakım kişi, kurum ve yapıların kasıtlı olarak yalan haber ürettiğini bu haberler ile kitleleri tahrik etmek veya psikolojik olarak etkilemek istedikleri de vakıadır. Toplumun bazı kesimleri de isteyerek veya istemeyerek bu yalanlara ortak olmaktadır.

Kur'ân Müreysî Gazvesi sonrası basit bir olay üzerinden Müslümanların arasını bozmaya çalışan kişinin söylemlerini tekzip ederek sadece ilgili ayetlerin indiği dönemdeki insanlara değil, öncelikle müminlere bilahare inanmasa bile tüm insanlara bir mesaj vermektedir. Bu bağlamda, insanlar arasında vuku bulan olaylarda insanları 'ötekileştiren' ve bu argüman ile kitleleri tahrik eden kişi ve gruplara asla prim verilmemesi gerektiğine vurgu yapılmaktadır. Mezkûr kişi ve olay üzerine inzal olan Münâfıkûn Sûresi'nin ilgili ayetlerinin evrensel ve aktüel muhatapları da benzer şekilde toplumu ayrıştırmaya çalışan tüm kişi ve kliklerdir. Bireylere düşen görev bir bilgi veya haberi din, mezhep veya etnik unsur bağlamında değerlendirme yanlışından uzak durmalarıdır. Bu bağlamda suçun bireysel olduğunu bilerek, sosyal medya platformlarında yer alan ve 'öteki' üzerinden nefret söylemi dillendiren, kitleleri provoke eden her türlü paylaşımdan uzak durmak ve ihtiyatlı davranmaktır.

Kur'ân sadece bireylerin değil, toplumların da bazı durumlarda sorumlulukları olduğunu İfk hâdisesi bağlamında dile getirir. İlgili hadise sonrası münafıklar Hz. Peygamber'in (a.s) muhterem eşini kirli bir fiilin öznesi olarak göstermeye çalışmışlardır. İlahi metin münafıkların yaptıklarına karşı dünyevi bir cezaya vurgu yaparken özellikle Müslümanları topluca ihtar eder. Zira toplumun neredeyse tümü bu olay karşısında 'bunu dillendirmek bize yakışmaz' demesi gerekirken, basit bir olaymış gibi dilden dile aktarmıştır. Kur'ân bu düşüncenin yanlışlığına vurgu yaparken günümüz toplumlarına da evrensel bir ahlaki öğreti sunmaktadır. O da toplumun da bireylerin mağduriyetleri karşısında sorumlu davranması gerekliliğidir. Zira toplumdaki bireyler eğer bir yanlışa karşı ortak tavır koymazlarsa o yanlışın toplumda yaygınlaşması gibi bir sonuç ile karşılaşabiliriz. Nitekim sosyal medyada beğenilme veya gündemde olma adına mahremiyet ihlallerinin günden güne arttığı bir zaman diliminde yaşamaktayız. Toplum bireyleri de bu mahremiyet ihlallerine meşruiyet kazandıracak yaklaşımlar içerisinde bulunabilmektedir. Bunun çözümü, toplumdaki tüm bireylerin ‘bunu yapmak bize yakışmaz' bilinciyle dikkatli ve sorumlu davranmasıdır. 
Kur'ân Mescid-i Dırar örneği bağlamında kutsalı kötü emellerine araç edinen tipolojilerin niyetini ifşa etmiş ve müminlerin böylesi kişi ve girişimlere karşı tedbirli olması gerektiğine dikkat çekmiştir. Zira münafıklar kötü planlarını daha etkili bir şekilde işlevsel kılmak için kutsalı da araç edinmekten çekinmemişlerdir. Bunun en güzel örneğini ülkemizde asıl amacı farklı olan dini yapılarla acı bir tecrübe ile yaşadık. Niyetlerinin dine ve vatana hizmet eden eğitimli gençler yetiştirmek olduğunu söyleyen gruplar dinin tüm kutsal değerlerini istismar etmekten çekinmemişlerdir.

Kur'ân geniş kitlelere ulaşabilme imkânı vesilesiyle münafıkların kirli eylem, söylem ve planlarını ifşa etmek gibi bir rol üstlenmiştir. Bu yönüyle yaptığı şey günümüzde yalan haberlere karşı sosyal medya platformlarındaki enformasyonla benzer bir mahiyettedir ve nüzul sürecinde Kur'ân'ın bir nevi sosyal medya rolü vardır. Masum insanlara yapılan iftiralara ve müdahale ederek insanların onur ve izzetini tezkiye ederken, muhataplara cezai müeyyideler getirerek sosyal medyada kişilerin haklarını ihlal edenlere ceza verilebileceğine zımnen işaret etmektedir. Daha da önemlisi bireylerin topluma, toplumun da bireylere karşı sorumlulukları olduğunu izhar ederek sosyal medya sorumluluğuna temas etmiştir. Özellikle 'ötekileştiren' ve 'ayrıştıran' içeriklere sahip bilgi ve haberlere karşı ihtiyatlı olunması gerektiğinin altını çizerek, böylesi bilgilerin konunun uzmanlarına iletilmeden ve teyit edilmeden paylaşılmamasına vurgu yapmaktadır. Aksi takdirde meydana gelebilecek menfi sonuçlar sadece bireyler için değil, tüm toplum için yıkıcı bir etki oluşturabilir. 


\section{Kaynakça}

Akpınar, M. Raşit. 'İslam Hukuku Açısından Sosyal Medya', Süleyman Demirel Üniversitesi Sosyal Bilimler Enstitüsü Dergisi 28/3 (2017) 493-509.

Aksu, Ali. "ifk Hadisesi ve Sonuçlarının iffet Açısından Değerlendirilmesi", Din ve Hayat: İstanbul Müftülüğü Dergisi, 19/1 (2013), 84-92.

Algül, Hüseyin. "Mescîd-i Dırâr". Türkiye Diyanet Vakfı İslam Ansiklopedisi. 29/272-273. Ankara: TDV Yayınları, 2004.

Ateş, Süleyman. Yüce Kur'an'ın Çağdaş Tefsiri. 11 Cilt. İstanbul: Yeni Ufuklar Neşriyat, 1988.

Begavî, Ebû Muhammed Hasan b. Mesûd. Tefsîru'l-Begavî: Meâlimu't-tenzîl. Thk. Muhammed Abdullah en-Nemr. 8 Cilt. Riyad: Dâru Tayyibe li'n-Neşr, 1989.

Beydâvî, Nâsırüddîn Ebû Saîd Abdullāh b. Ömer b. Muhammed. Tefsîru'l-Beydâvî: Envâru'Tenzîl ve Esrâru't-te'vîl. Thk. Muhammed Abdurrahman el-Maraşlî. 5 Cilt. Beyrut: Dâru İhyâi'tTurâsi'l-'Arabî, 2001.

Çalık, Nilüfer Sena. "Beden, Mesken ve Bilgi Mahremiyeti Açısından Sosyal Medyadaki Tasarrufların Fıkhî Açıdan Değerlendirilmesi". Türk Akademik Araştırmalar Dergisi 3/1 (Haziran, 2018), 25-44.

Çekiç, Sevdegül - Ayengin, Tevhit. "Sosyal Medyadaki Mahremiyet İhlallerinin Bazı Fıkhî Yansımalarına Dair", Mütefekkir, 8/15 (Haziran 2021), 71-93.

Derveze, Muhammed İzzet. et-Tefsîru'l-ḥadîs: tertibu's-süver ḥasebe'n-nüzûl. 10 Cilt. Kahire: Dâru ihyâi'l-Kutubi'l-Arabi, 1383/1964.

Ebû Hayyân, Muhammed b. Yusuf. Tefsîru'I-Baḥri'l-muhît. Thk. Adil Ahmed Abdulmevcud. 8 Cilt. Beyrut: Dâru'I-Kutubi'l-'Illmiyye, 1993.

Gül, Recep Emin. "Sosyal Medyada Hadis Kullanımı -Facebook ve Twitter Özelinde-". Yüzüncü Yıl Üniversitesi Sosyal Bilimler Enstitüsü Dergisi 30/2 (Bahar 2016), 163-182.

Ilgın, Hicran Özlem. "Sosyal Medyada Dezenformasyon ve Halkla İlişkiler İlişkisi". Illetişim Çalışmaları Dergisi, 7/2 (2021), 303-322.

İbn Âşûr, Muhammed Tâhir. Tefsîru't-Taḥrîr ve't-tenvîr. 30 Cilt. Tunus: ed-Dâru't-Tunusiyye, 1984.

İbn Atiyye, Ebû Muhammed Abdullah b. Gālip. el-Muharreru'l-vecîz fî tefsîri'l-Kitâbi'I-'Azîz. Thk. Abdusselam Abduşşâfî. 6 Cilt. Beyrut: Daru'l-Kutubi'l-'ilmiyye, 2001.

Kara, Seyfullah. "ifk Olayının Etkileri ve Olayla İlgili Ortaya Konan Tavırlar". Atatürk Üniversitesi Illahiyat Fakültesi Dergisi, 15/1 (2001) 343-382.

Kayacı, Eyyüp. "İmam Hatip Lisesi Öğrencilerinin Sosyal Medyaya Illişkin Tutumlarının İncelenmesi". Trabzon Ilahiyat Dergisi 8/1 (Güz: 2021), 39-74.

Mâturîdî, Ebû Mansur Muhammed. Tevilâtu ehli's-sünne: Tefsîru'I-Mâturîdî. thk. Mecdî Basillûm. 10 Cilt. Beyrut: Dâru'l-Kutubi'l-'Illmiyye, 2005.

Mâverdî, Ebu'I-Hasan Ali b. Muhammed b. Habîb. en-Nüket ve'l-'uyûn: tefsîru'I-mâverdî. thk. Abdulmaksûd bin Abdurrahîm. 6 Cilt. Beyrut: Dâru'I-Kutubi'l-'ilmiyye, ts.

Mevdûdî, Ebu'I-'Alâ. Tefhimu'I-Kur'ân. 7 Cilt. İstanbul: İnsan Yayınları, 2000.

Râzî, Fahreddîn. Mefâtîhư'I-gayb: tefsîru'r-Râzî. 32 Cilt. Lübnan: Dâru'I-Fikr Li't-Tabaa ve'nNeşr, 1981. 
Sefer, Yavuz. "illahiyat Fakültesi Öğrencileri Örnekleminde Problemli Sosyal Medya Kullanım Ölçeği Geliştirme: Geçerlik-Güvenirlik Çalışması". Harran Üniversitesi Illahiyat Fakültesi Dergisi 26/44 (Bahar: 2020), 109-124.

Sıcak, Ahmet Sait. "Sosyal Medyada Kur'ân Kaynaklı Paylaşımlar -Saffât Suresi 25. Ayet Özelinde-". Modernleşme Sürecinde Müslümanlar. Ankara: Nobel, 2018.

Suyûtî, Celâleddîn. ed-Dürrü'l-menŝur fi't-tefsîri bi'l-me'ŝûr. Thk. Abdullah bin Abdulmuhsin et-Türkî. 17 Cilt. Kahire: Merkezu Hicr li'l-Buhûs, 2004.

Şahin, Harun. "Kuran Perspektifinden İnsan Onuru, Mahremiyet ve Ifk Hadisesi", Din Gelenek ve Ahlak Bağlamında Mahremiyet Algıları Sempozyumu (27-29 Mart 2015), 503-515.

Şevkânî, Muhammed b. Ali b. Muhammed. Fetḥu'l-kadîr: el-câmiu beyne fenniyyi'r-rivâyeti ve'd-dirâyeti min i'Imi't-tefsîr. Thk. Abdurrahman Umeyra. 5 Cilt. y.y: Dâru'I-Vefâ, ts.

Taberî, Ebû Câfer Muhammed b. Cerîr. Câmiu'I-beyân an te'vîli âyi'l-Kur'ân. Thk. Abdullah bin Abdulmuhsin et-Türkî. 26 Cilt. Kahire: Merkezu'l-Buhûs ve'd-Dirâsâti'l-Arabiye, 2001.

Tabersî, EbûAli el-Fadl b. Hasan. Mecmeu'I-beyân fî tefsîri'l-Kur'ân. 10 Cilt. Beyrut: Dâru'IU'lûm, 2005.

Toktay, Yakup - Kırık, Ali Murat. "Sosyal Medyada Dezenformasyon, Manipülasyon ve Propaganda Etkisi: Zeytin Dalı Harekatı Örneği". Sosyal Bilimler Alanında Akademik Çalışmalar. Ed. Hasan Babacan. Ankara: Gece Kitaplığı, 2020.

Tûsî, Ebû Ca'fer Muhammed b. Hasan. et-Tibyân fîtefsîri'l-Kur'ân, thk.Ahmed Habîb el-Âmilî. 10 Cilt. Lübnan: Dâru ìnyâi't-Turâsi'l-'Arabî, ts.

Vâhidî, Ebu'l-Hasan Muhammed. el-Vasît fî tefsîri'l-Kur'âni'l-Mecîd. Thk. Adil Ahmed Abdulmarsud. 4 Cilt. Beyrut: Dâru'I-Kutubi'l-'Ilmiyye, 1994.

Yıldız, İbrahim. "Hucurât Sûresinin 6. Âyeti Bağlamında Sosyal Medyadaki Gerçekdışı Haberler". Eskişehir Osmangazi Üniversitesi Illahiyat Fakültesi Dergisi, 8/2 (Eylül 2021), 158-182.

Zemahşerî, Cârullah Ebu'l-Kāsım Muhammed b. Ömer. el-Keşşâf an haḳāiḳi gavâmidi'ttenzîli ve 'uyûni'l-ekvali fi vucûhi't-te'vîl. Thk. Adil Ahmed Abdulmevcud. 6 Cilt. Riyad: Mektebetu'l-Abikan, 1998. 